\title{
Applications of Nettle Fibre in Textile: A Brief Review
}

\author{
Kartick K. Samanta, A.N. Roy*, H. Baite, S. Debnath, L. Ammayappan, L.K. Nayak, \\ A. Singha and T.K. Kundu
}

ICAR-National Institute of Natural Fibre Engineering and Technology, 12 Regent Park, Kolkata, West Bengal, India

*Corresponding author: a_n_royin@yahoo.co.in

Received: $13-03-2021$

Revised: 21-05-2021

Accepted: 09-06-2021

\begin{abstract}
Nettle fibre production in Europe began in the $19^{\text {th }}$ century and during the First and Second World Wars nettle fibre was promoted as a substitute for cotton. In the 1940s, about 500 ha of nettle fibres were cultivated in Germany and Austria and used for textile production. However, processing facilities for nettle fibres were destroyed during the Second World War and other cost-effective fibres became more readily available. At present, acceptable methods and technology for large scale processing of nettle fibre do not exist. However, a recent survey on processing method for flax and hemp fibres suggests that same might be adapted for processing of nettle fibres. Nettle fibre extracted from the bark of the plant is subject to retting process/ analogous process. Fibre can be blended with other natural or synthetic fibres for making blended yarns with requisite blend ratios to developed fabric, which can be used for developing fashion apparel/ garments, handicrafts products, home textile and technical textile. Fibre properties could be further enhanced by suitable chemical treatment. Nettle fabrics in pure or in blends exhibit good oil sorption properties.
\end{abstract}

Keywords: Nettle fibre, Yarn, Fabric, Chemical treatment, Oil sorption, Fibre processing

Clothing is one of the essential needs of the humanbeing and it has a long history of use for over 7,000 years (Samanta et al. 2016a). As far as the basic raw material of the textile is concerned, the natural fibres are the key for the growth of the sustainable and green industry. Natural fibres like silk, wool, cotton, flax, ramie, and jute, and man-made fibres like, viscose, cellulose acetate, polyester, acrylic and nylon are used in the production of traditional to apparel, home and technical textiles (Chattopadhyay et al. 2021; Samanta et al. 2016b; Teli et al. 2021; Chattopadhyay et al. 2020; Samanta et al. 2020; Roy et al. 2019; Samanta et al. 2021). Locally available agricultural plants waste may be utilized for extraction of useful fibres for textile application viz., Okra, Banana, Pineapple, Coconut and Cornhusk (Chattopadhyay et al. 2020; Kambli et al. 2018; Gupta et al. 2019; Samanta et al. 2016a). In this direction, the nettle plant may also be used for extraction of quality fibre for textile application. The perennial stinging nettle (Urtica dioica L.) is a common herbaceous plant that grows on ruderal sites, in gardens, at the edges of forests and in wooded areas of riverine floodplains. Urticaceace nettle family contains around 500 species. Out of them, Girardinia diversifolia produces nettle fiber (Debnath, 2015). Similar to flax (Linum usitatissimum L.) and hemp (Cannabis sativa L.), nettle fibres were used for the production of textiles in central Europe before the introduction of cotton (Gossypium sp.) (Vogl and Hartl, 2003). Most of us try to avoid stinging nettles, but soon we may be tempted to put them right next to our skin. Clothing made from stinging nettle fibre is about to hit the catwalk and an Italian fashion house has started to produce a range of nettle

\footnotetext{
How to cite this article: Samanta, K.K., Roy, A.N., Baite, H., Debnath, S., Ammayappan, L., Nayak, L.K., Singha, A. and Kundu, T.K. (2021). Applications of Nettle Fibre in Textile: A Brief Review. International Journal of Bioresource Science, 08(01): 39-45.
}

Source of Support: None; Conflict of Interest: None (6) 8 
jeans and jackets. In the hunt for new, ecologically friendly fabrics, stinging nettle fibre has come up in a popular way. Clothing made of nettles fibre is not a new idea; for the past 2,000 years, people have worn fabrics made of this stinging plant. But nettles lost their popularity, when cotton arrived in the $16^{\text {th }}$ century, as cotton was easier to harvest and spin (http://www.swicofil.com/products/016nettle.html). Nettles made a brief comeback during the First World War, when Germany suffered a shortage of cotton and the nettle was used to produce German army uniforms. Now, with the new advancements in spinning technologies and cross-breeding to produce super high fibre plants mean that stinging nettles are set to become in the latest fashion.

The nettle is a highly successful plant found all over the temperate areas of the world. It spreads by means of seeds and underground rhizomes that creep around just under the surface of the soil. The jagged leaves held in pairs along the square stems are easily recognizable, particularly after having experienced the sting. The plant itself is variable growing from 0.6 to 2 meters plus in height and can be found in a variety of habitats and soil types. It prefers rich soils and therefore does well around human settlements benefiting from the waste. Several species of the nettle family (Urtica ceae) produce bast fibres similar to flax, and many of those species have been used to produce fibre for making textiles and clothing for thousands of years. Nettle fibre possesses characteristics of low density, hollow structure, surface waxiness, biodegradability, and reusability (Brindha et al. 2019). Nettle fibre fibre is stronger, environment friendly and finer than other bast fibres. Alkali treatment can play a significance role in enhancing the tensile properties of nettle fibres for its technical application. It could witness in increase in crystallinity, appearance, tensile strength and elongation at break with minimum changes in initial modulus. The fibre has higher oil absorbency attribute than many other natural fibres. With optimum alkali treatment, the tensile strength can be increased to $30 \%$, elongation at break to $71 \%$ with $9 \%$ reduction in initial modulus with respect to the untreated nettle fibres (Kumar and Das, 2017). Nettle fibre and/or fabrics and after its treatment with hot water, hydrochloric acid and acetylation show increase in oil absorbency having potential application in oil spill clean-up (Viju et al. 2019a; Viju and Thilagavathi, 2020b; Viju et al. 2020; Viju and Thilagavathi, 2019b).

Hand-spun yarn is made from nettle fibre to prepare hand spun twines using a flywheel for fishing purposes. The tensile strength of nettle fibre ranges from 24 to $62 \mathrm{cN} /$ tex, which is much higher than other natural fibres like cotton, silk and wool fibres. The fibre is very light in weight in comparison to other natural fibres with extension little higher than the jute fibre (2\%) (Debnath, 2015; Debnath, 2017). Nettle fibre can be blended with wool, cotton, ramie, flax, viscose and other fibres for developing fashion apparel/ garments and sustainable luxury textiles products (Radhakrishnan \& Preeti, 2015). There are two main nettle fibre producing species namely, European nettle and Himalayan nettle.

\section{European nettle or Stinging nettle}

European nettle is difficult to grow commercially (http://www.wildfibres.co.uk/html/nettle_hemp. html). Ramie, on the other hand, produces a fine fibre that is produced commercially in China and Japan. Himalayan nettle is a large nettle grown mainly in the Himalayan region. In all these species, the fibre comes from the stem and, incidentally, there is no sting left in the extracted fibre. The common stinging nettle, Urtica dioica, is a widely distributed plant that grows very easily on damp disturbed ground. It has been used as fodder for livestock and also to make tea, beer, rennet and a plant dye. It is similar to flax and hemp fibre, and can be used to produce a fine linen cloth. The first known nettle textile find in Europe is from the late Bronze Age in Voldtofte in Denmark (Barber) and there is an evidence of nettle cloth production from Scandinavia, Poland, Germany and Russia. It does not appear to have been as widely used for fibre and textile production as flax and hemp are used, except in the northern, central and eastern Europe. In Poland, nettle thread was used until the $17^{\text {th }}$ century, when it was replaced by silk, and nettle cloth continued to be produced in Scandinavia, and also in Scotland until the $19^{\text {th }}$ century, where it was known as Scotch cloth. In the first World War, the shortage of cotton resulted in the Germans cultivating nettles to make clothing. The Voldtofte textiles had been assumed to be flax, as it had the Oseberg Ship textiles, until they were examined by a nettle expert and shown to be made from nettle 
fibre not flax (Barber). Nettle fibres are white, silky, up to $50 \mathrm{~mm}$ long, and produce a finer and silkier fabric than flax, so that it is possible to make fine linens for the elite end-user.

\section{Himalayan nettle or Allo (Girardinia diversifolia)}

Although called Himalayan nettle, this plant grows wild in Africa and several Asian countries. In Nepal, Himalayan nettle grows wild in fertile forest soils in altitudes ranging from 1200 to 3000 metres. It can be an annual or a short-lived perennial plant up to 1.5 metres in height. All parts of the plants are covered in thorn like stinging hairs that can cause painful rashes. Himalayan nettle plants have been uses for centuries as a fibre resource. The fibre comes from the stem is very long and strong, similar to ramie. After cutting the stem, the bark is removed/ peeled and fibre is extracted. The extracted nettle fibre is used for manufacturing summer and winter garments, sportswear garments in the textile industry. A large quantity of raw nettle has been reported to be available by the Uttarakhand Bamboo and Fibre Development Board (UBFDB) having high potential as a handicrafts sector, providing value to tourism industry and high export potential.

\section{Processing of nettle fibre}

Retting: This is a controlled rotting to remove gummy (pectinous) substances that glue the fibres together, which can be carried out in a number of ways as stated below:

- Water retting - the stalks are left in water in a pond/ flowing water, acted upon by action of bacteria.

- Dew retting - the stalks are left out in the field for 6 weeks, and are acted upon by fungi. Currently dew retting is the dominant method.

- Chemical retting - the stalks are placed in chemical solutions (alkali treatment). Pretreatment (bioscouring) of fibre was required to remove the impurities present in the fibre and bio softening to reduce the flexural rigidity of the fibre (Radhakrishnan1 and Preeti, 2015). However, the process tends to damage the fibres and also leads to environmental pollution.

Breaking, scutching and hackling: After the retting, a sequence of processes is followed to remove the fibres from the woody stalks as follows: first breaking them, then scraping, or scutching. Hackling is a combing process is used to separate the long fibre from the short fibres and to also remove the remaining woody material.

\section{Properties of nettle fibre and its chemical treatment}

The nettle fibre (Urtica dioica L.) has a diameter, fibre length and tensile strength of 47 to $19 \mu \mathrm{m}$, 43 to $58 \mathrm{~mm}$ and 24-60 cN/tex with an elongation from 2.3-2.6 \%, respectively suitable for industrial applications (Bacci et al. 2009). The average value of ultimate stress, Young's modulus and average diameter for stinging nettle fibres are $1594 \mathrm{MPa}$, $87 \mathrm{GPa}$ and $19.9 \mu \mathrm{m}$ with density of $0.72 \mathrm{~g} / \mathrm{cm}^{3}$. The light specific weight and high ultimate stress properties of stinging nettle fibre possess good potential to be used as fibre reinforced composite, which can produce lighter and stronger material (Suryawan et al. 2017; Debnath, 2015). Chemical constituent of nettle fibre shows the presence of $85 \%$ cellulose including hemicellulose, $\sim 5 \%$ watersoluble matter, $2.12 \%$ lignin, $2.68 \%$ ash, $2.16 \%$ wax and about $3 \%$ other materials (Thilagavathi and Karan, 2018). In order to improve the physical and mechanical properties of nettle fibre, it was subject to alkali treatment using sodium hydroxide $(\mathrm{NaOH})$ solution in different concentration. The fibre was subjected to $0.5 \% \mathrm{NaOH}$ treatment at $30^{\circ} \mathrm{C}$ for 30 min and $10 \% \mathrm{NaOH}$ treatment at $100^{\circ} \mathrm{C}$ for 6 hours (Kumar and Das, 2017). This leads to improvement in many fibre properties. An untreated nettle fibre has a tensile strength of $4.10 \mathrm{~g} / \mathrm{den}$ and $2.6 \%$ tensile strain along with initial modulus of $184 \mathrm{~g} / \mathrm{den}$. These fibre properties changed notably in the $0.5 \%$ and $10 \% \mathrm{NaOH}$ treated samples e.g., $5.57 \mathrm{~g} / \mathrm{den}$ and $3.54 \mathrm{~g} / \mathrm{den}$ for tensile strength, $3.6 \%$ and $2.81 \%$ for tensile strain, and $180 \mathrm{~g} / \mathrm{den}$ and $146 \mathrm{~g} / \mathrm{den}$ for initial modulus, respectively. The untreated fibre has a diameter and fineness values of $52 \mu \mathrm{m}$ and 24.6 denier and it reduced to $50 \mu \mathrm{m}$ and 24 denier and $38 \mu \mathrm{m}$ and 20.1 denier in the $0.5 \%$ and $10 \%$ alkali treated samples, respectively. Nettle fibre without any chemical treatment possesses crystallinity index of $67 \%$ and it increased to $68.6 \%$ and $68.4 \%$ in the $0.5 \%$ and $10 \%$ alkali treated samples, respectively (Kumar and Das, 2017). In another paper fibre properties were estimated as follows: fibre length 
10-90 mm, strength $33.5 \mathrm{~g} /$ tex, and elongation 2.7 mm (Radhakrishnan and Preeti, 2015).

\section{Spinning of nettle fibre}

Spinning of nettle fibre is much comparable as spinning any other bast fibres. The method of spinning depends on the length of the fibre, fibre quality, what we want to make from this yarn, and pre-treatment imparted for making better yarn. Wild nettle yarn is not coming in regular colour and regular yarn sizes because, it is spun by hand and by natural process. Now the different manufacturer is using the hemp and nettle yarns to blend with cotton, soybean, bamboo, linen and other natural fibres. Main end uses are hand tuft knotted carpet and knitting wear. An attempt was made to produce yarn from the $100 \%$ nettle fibre, although the yarn quality was not satisfactory (Bodros and Baley, 2008). However, it was observed that blending of nettle fibre with other fibres enhance the spinning performance as well as yarn quality. Friction spinning technology was considered to produce yarns from nettle fibre for producing fashionable upholstery (Shaolin et al. 2005). The organic cotton and bamboo fibres were blended with the nettle fibres for yarn development and optimum results were found, when the blend ratio was kept at 50:50 (Radhakrishnan and Preeti, 2015). The blended yarns of $10^{\text {s }}$ count were prepared and compared with similar yarn count produced from $100 \%$ organic cotton and $100 \%$ bamboo fibre. Tensile strength of the blended single yarns was in the range of 66.2 to $67.6 \mathrm{gf} / \mathrm{tex}$, which are similar to yarns produced from $100 \%$ organic cotton or bamboo fibres. Elongation of the blended yarns was found to $17 \mathrm{~mm}$ for nettle/organic-cotton blend and $31 \mathrm{~mm}$ for nettle/bamboo fibres blend. The schematic of process flow chart for nettle fabric manufacturing is depicted in Fig. 1.

\section{Nettle fabric}

An Italian fashion company introduced an environmentally friendly alternative to contemporary textiles and dyes. They have made woven fabric from the stinging nettle fibres, used in the past for the uniforms of Napoleon's soldiers and also to replace cotton yarns that were unavailable during World War I and II. The name URTICA, as it is called in Europe, derives from the Latin word "uro", which means to burn. Fabric can be developed from nettle yarns blended with other natural fibres yarns (cotton, bamboo etc.) in different proportions, which have good potential to be used for home textiles, technical applications, fibre composite and making handicrafts products. Woven towel fabrics was produced from the $100 \%$ nettle fibres and properties were evaluated in details (Sabir and Unal, 2017). Woven fabrics either from $100 \%$ nettle or in combination with fibres like, flax, cotton, viscose and wool have been prepared for their application in apparel. Bhardwaj and Pant, 2014 tried to produce nettle and acrylic blended woven fashion textiles.

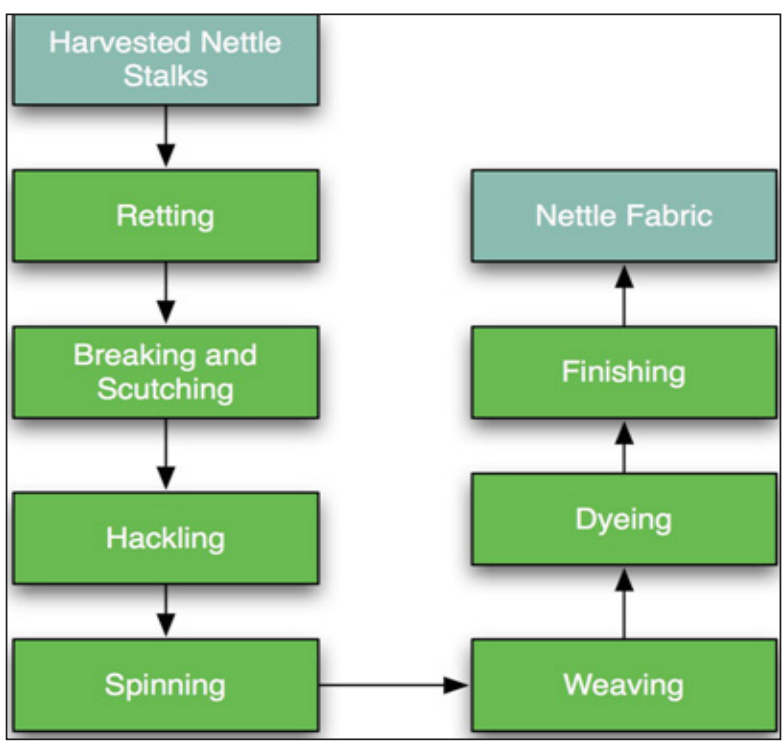

Fig. 1: Schematic process flow chart for making nettle fabric

Similar to woven fabric, nonwoven fabrics has been developed from the $100 \%$ nettle for its application in oil spill removal, as discussed below in details (Viju and Thilagavathi, 2019). The same research group also reported the development of needlepunched nonwovens fabrics from the nettle and polypropylene fibres (Brindha, Thilagavathi, and Viju 2019). Thermal resistance and moisture management properties of the nettle/polyester fibres mixture nonwoven fabrics have also been reported (Sinha et al., 2019). Comfort properties of nettle nonwoven fabric with areal densities of $150 \mathrm{~g} / \mathrm{m}^{2}, 250 \mathrm{~g} / \mathrm{m}^{2}$ and $350 \mathrm{~g} / \mathrm{m}^{2}$ was assessed (Viju and Thilagavathi, 2020c). The maximum water absorbency of $494 \%$ and air permeability of $79 \mathrm{~cm}^{3} /$ $\mathrm{cm}^{2} / \mathrm{s}$ and minimum thermal conductivity of 0.0251 $\mathrm{W} / \mathrm{mK}$ was measured, when the nonwoven process parameters were kept as follows: needle punch 
density of 75 punches $/ \mathrm{cm}^{2}$, needle penetration of 8 $\mathrm{mm}$ and fabric areal weight of $150 \mathrm{~g} / \mathrm{m}^{2}$; such fabric may effectively be used for apparel applications. Woven fabrics were developed from nettle/organic cotton and nettle/bamboo fibres blended yarns, as weft. Fabric properties were compared with the $100 \%$ organic cotton and bamboo fabric (same yarn in both warp and weft direction) (Radhakrishnan and Preeti, 2015). An increase in abrasion resistance, strength and elongation was noticed in the blended fabrics as compared to the control fabrics produced from the either $100 \%$ organic cotton or bamboo fabrics.

\section{Oil absorption property}

The Himalayan nettle (Girardinia diversifolia) filaments received from the Nepal was used for oil absorption study against engine oil (density 0.90 $\mathrm{g} / \mathrm{cm}^{3}$ ) and diesel oil (density $0.82 \mathrm{~g} / \mathrm{cm}^{3}$ ) (Viju and Thilagavathi, 2020a). Alkali treatment of fibre was carried out by changing the process parameters in three incremental steps viz., time $(60 \mathrm{~min}, 90$ min, $120 \mathrm{~min})$, temperature $\left(40{ }^{\circ} \mathrm{C}, 70{ }^{\circ} \mathrm{C}, 100{ }^{\circ} \mathrm{C}\right)$ and the $\mathrm{NaOH}$ concentration $(1 \%, 2 \%, 3 \%)$, solid to liquid ratio $(1: 10,1: 20,1: 30)$. In one batch, 10 $\mathrm{g}$ of cleaned nettle fibres was put in $500 \mathrm{ml}$ of alkaline solution. As far as the effect of treatment time is concerned, oil absorbency increases till 90 min and thereafter decreases. Oil absorbency also followed similar a trend, when the temperature was increased up to $70{ }^{\circ} \mathrm{C}$. The change in $\mathrm{NaOH}$ concentration also exhibited a similar trend. The same research group also studied the oil absorbency of nettle fibre, when it was subjected to hot water treatment, adopting an environment friendly approach (Viju and Thilagavathi, 2020b). Fibre was initially subjected to mild alkali treatment using $2 \%$ sodium hydroxide at room temperature for $60 \mathrm{~min}$ to remove the barks attached on the fibre surface and also to soften the fibres. Subsequently, $10 \mathrm{gm}$ of cleaned fibre was treated with hot water $(500 \mathrm{ml})$ in a batch process keeping the temperatures at 40 ${ }^{\circ} \mathrm{C}, 60{ }^{\circ} \mathrm{C}, 80{ }^{\circ} \mathrm{C}$ and $100{ }^{\circ} \mathrm{C}$ for $60 \mathrm{~min}$. It can be seen that oil absorbency of nettle fibres increases with an increase in treatment temperature. The maximum achievable oil absorbency was $15.89 \mathrm{~g} / \mathrm{g}$ against engine oil and $13.10 \mathrm{~g} / \mathrm{g}$ against diesel oil, when the treatment was performed at $100{ }^{\circ} \mathrm{C}$. In this direction, oil sorption capacity of nettle fibrous assembly and needle-punched nonwoven structures made of $100 \%$ nettle and nettle/kapok blends ratios of 50/50 and 75/25 has also been reported (Thilagavathi and Karan, 2018). The fibre diameter of $72 \mu \mathrm{m}$, density of $1160 \mathrm{~kg} / \mathrm{m}^{3}$, tenacity of $39 \mathrm{~g} /$ denier and elongation at break of $4.3 \%$ was used for making nonwoven fabric. It showed the maximum oil sorption capacity of $56 \mathrm{~g} / \mathrm{g}$ and $23.9 \mathrm{~g} / \mathrm{g}$ by the nettle fibre nonwoven against high-density oil and diesel oil, respectively. In the case of kapok fibre blended nonwoven, with increasing the content of kapok fibre, the oil sorption capacity increases. In 50/50 nettle/kapok fibres blended nonwoven, the maximum oil sorption values were $28.5 \mathrm{~g} / \mathrm{g}$ and 22.5 $\mathrm{g} / \mathrm{g}$ for high density oil and diesel oil, respectively.

\section{CONCLUSION}

Currently no commercial production of nettle fibre as well as nettle textiles are available from the inventories of the major natural textile producers and traders. Opportunities for successful organic cultivation and processing of nettle fibre lie in (1) trend towards goods produced in an environmentally way, (2) increase in the range of domestic raw fibre materials, in addition to flax and hemp in temperate climates, (3) production of quality fibres, and (4) cultivation in more environmentally way. One may presume that the cultivation, processing and marketing of nettle fibre would be somewhat similar to those of flax and hemp. Due to the perennial cropping of nettle fibre and due to the fact that nettle can be used for fibre production from the second cultivation year on, cooperation between the farmers and processing companies should ensure demand for a longer period of time. At present, the limiting factors for nettle fibre production are the lack of (1) suitable harvesting technology, (2) large scale fibre processing method, and (3) large-scale textile processing. In-spite of many limitations, successful efforts have also been made to produce yarn either from 100\% nettle fibre or in blending with various natural and synthetic fibres. Woven as well as nonwoven textiles have also been developed and their properties have been evaluated in details keeping in mind for their various end applications. It was found that alkali treatment of nettle fibre could improve the properties. Nettle fabric could be used effectively in oil sorption. 


\section{ACKNOWLEDGEMENTS}

Authors are thankful to the CRP on Natural Fibre for sanctioning the project (code: CRP-NINFET 6) and for financial support.

\section{REFERENCES}

1. Bacci, L., Baronti, S., Predieri, S. and di Virgilio, N. 2009. Fiber yield and quality of fibre nettle (Urtica dioica L.) cultivated in Italy. Industrial Crops and Products, 29(2-3): $480-484$.

2. Bhardwaj, S. and Pant, S. 2014. Properties of nettle-acrylic blended yarn. Journal of the Textile Association, 75(1): 28-31.

3. Bodros, E. and Baley, C. 2008. Study of the tensile properties of stinging nettle fibers (Urtica dioica). Materials Letters, 62(14): 2143-45.

4. Brindha, R., Thilagavathi, G. and Viju, S. 2019. Development of nettle-polypropylene-blended needle-punched nonwoven fabrics for oil spill cleanup applications. Journal of Natural Fibers, 17(10): 1439-1453.

5. Chattopadhyay, S.N., Pan, N.C., Roy, A.N. and Samanta, K.K. 2020. Pretreatment of jute and banana fibre - its effect on blended yarn and fabric. Journal of Natural Fibres, 17(1): 75-83.

6. Chattopadhyay, S.N., Pan., N.C., Roy, A.N., Samanta, K.K. and Khan, A. 2021. Hybrid bleaching of jute yarn using hydrogen peroxide and peracetic acid. Indian Journal of Fibre and Textile Research, 46: 78-82.

7. Debnath, S. 2015. Great potential of stinging nettle for sustainable textile and fashion. In Handbook of sustainable luxury textiles and fashion, Springer, Singapore, pp. 43-57.

8. Debnath, S. 2017. Sustainable production of bast fibres. In Sustainable fibres and textiles, Woodhead Publishing, pp. 69-85.

9. Gupta, P.K., Patra, S. and Samanta, K.K. 2019. Potential of Okra for Application in Textiles: A Review. Journal of Natural Fibres, pp. 1-13. https://doi.org/10.1080/15440478 .2019.1697997.

10. Kambli, N.D., Samanta, K.K., Basak, S., Chattopadhyay, S.K., Patil, P. G. and Deshmukh, R. R. 2018. Characterization of the corn husk fibre and improvement in its thermal stability by banana pseudostem sap. Cellulose, 25(9): 5241-5257.

11. Kumar, N. and Das, D. 2017. Alkali treatment on nettle fibers: Part I: investigation of chemical, structural, physical, and mechanical characteristics of alkali-treated nettle fibers. The Journal of the Textile Institute, 108(8): 1461-1467.

12. Radhakrishnan, S. and Preeti, A. 2015. Development of Fabric from Girardina Diversifolia Stem Fibres and its Blends. International Journal of Innovative Research in Science, Engineering and Technology, 4(11): 10499-10506.

13. Roy, A.N., Samanta, K.K., and Patra, K. 2019. Physicochemical properties of black yak fibre and its modification for blending with jute fibre. Journal of Natural Fibres, 16(2): 225-236.

14. Sabir, E.C. and Unal, B.Z. 2017. The using of nettle fiber in towel production and investigation of the performance properties. Journal of Natural Fibers, 14(6): 781-87.

15. Samanta, K.K., Basak, S. and Chattopadhyay, S.K. 2016a. Potential of Ligno-cellulosic and Protein Fibres in Sustainable Fashion. In: Muthu S., Gardetti M. (eds) Sustainable Fibres for Fashion Industry, pp. 61-109, Springer, Singapore.

16. Samanta, K.K., Gayatri, T.N., Saxena, S., Basak, S., Chattopadhyay, S.K., Arputharaj, A. and Prasad, V. 2016b. Hydrophobic functionalization of cellulosic substrates using atmospheric pressure plasma. Cellulose Chemistry and Technology, 50(7-8): 745-754.

17. Samanta, K.K., Mustafa, I., Debnath, S., Das, E., Basu, G., and Ghosh, S.K. 2020. Study the thermal insulation performance of layered jute non-woven: A sustainable material, Journal of Natural Fibre, pp. 1-14. https://doi.org /10.1080/15440478.2020.1856274.

18. Samanta, K.K., Joshi, A.G., Jassal, M. and Agrawal, A.K. 2021. Hydrophobic functionalization of cellulosic substrate by tetrafluoroethane dielectric barrier discharge plasma at atmospheric pressure. Carbohydrate Polymers, 253: 117272.

19. Sinha, S.K., Sharma, A. and Maity, S. 2019. Thermal resistance and moisture management behaviour of nettle/ polyester nonwoven fabrics. Tekstilec, 62(4): 258-268.

20. Shaolin, X., Hong, S., Fengli, H., Aiming, X. and Xiaoyin, S. 2005. Technology research on friction spinning nettle core-spun yarn. Cotton Textile Technology, 9: 13-15.

21. Suryawan, I.A., Suardana, N.P.G., Winaya, I.S., Suyasa, I.B. and Nindhia, T.T. 2017. Study of stinging nettle (Urtica dioica L.) Fibers reinforced green composite materials: a review. In IOP Conference Series: Materials Science and Engineering, 201(1): 012001.

22. Teli, M.D., Pandit, P., Samanta, K.K., Basak, S. and Gayatri, T.N. 2021. Salt-free and low temperature colouration of silk using $\mathrm{He}-\mathrm{N}_{2}$ nonthermal plasma irradiation. Journal of Cleaner Production, 296: 126576.

23. Thilagavathi, G. and Karan, C.P. 2018. Investigations on oil sorption capacity of nettle fibrous assembly and $100 \%$ nettle and nettle/kapok blended needle-punched nonwovens. Journal of Industrial Textile, 49(40): 415-430.

24. Viju, S., Thilagavathi, G., Vignesh, B. and Brindha, R. 2019a. Oil sorption behaviour of acetylated nettle fiber. The Journal of the Textile Institute, 110(10): 1415-1423.

25. Viju, S. and Thilagavathi, G. 2019b. Oil spill cleanup by bonded nettle fibrous mat. Journal of the Institution of Engineers (India), 100(1): 93-100.

26. Viju, S. and Thilagavathi, G. 2020a. Effect of alkali treatment of nettle fibers on oil absorbency. Journal of Natural Fibers, pp. 1-10. https://doi.org/10.1080/1544047 8.2020 .1723776 . 
27. Viju, S. and Thilagavathi, G. 2020b. Hot Water Treatment on Nettle Fibers: An Environment-Friendly/Economical Process for the Production of Oil Sorbent. Journal of Natural Fibers, pp. 1-9. https://doi.org/10.1080/15440478 .2020.1761929.

28. Viju, S. and Thilagavathi, G. 2020c. Comfort Characteristics of Nettle Nonwoven Fabrics. Journal of Natural Fibers, 17: 1-8.

29. Viju, S., Thilagavathi, G. and Aarthy, S. 2020. Effect of hydrochloric acid treated nettle fibre on oil absorbency. Indian Journal of Fibre $\mathcal{E}$ Textile Research, 45(3): 332-337.
30. Vogl, C.R. and Hartl, A. 2003. Production and processing of organically grown fiber nettle (Urtica dioica L.) and its potential use in the natural textile industry: A review. American Journal of Alternative Agriculture, 18(3): 119-128.

31. http://www.swicofil.com/products/016nettle.html

32. http://www.wildfibres.co.uk/html/nettle_hemp.html 
